\title{
Context, contribution and characteristics of public spaces for place making in contemporary knowledge and innovation spaces. Observations from Brisbane, Australia
}

\author{
Surabhi Pancholi, Mirko Guaralda \\ Queensland University of Technology, Australia \\ surabhi.pancholi@student.qut.edu.au | m.guaralda@qut.edu.au \\ Tan Yigitcanlar \\ World Capital Institute, Australia \\ tan@worldcapitalinstitute.org
}

\begin{abstract}
The advanced era of knowledge-based urban development has led to an unprecedented increase in mobility of people and subsequent growth in new typologies of agglomerated enclaves of knowledge such as urban knowledge and innovation spaces. Within this context, a new role has been assigned to contemporary public spaces to attract and retain the mobile knowledge workforce by creating a sense of place. This paper investigates the context, characteristics and contribution of public spaces in facilitating place making in the globalised knowledge economy world. It takes an overall processbased approach to highlight the observations from Australia's new world city Brisbane to outline the application of urban design as a tool to create and sustain multi-dimensional place making in urban knowledge and innovation spaces, which caters diverse range of social, cultural and democratic needs. The study derives multi-layered permeability as the key character that defines the modified typology of public spaces and which is vital for making them more viable and adaptive as per the changing needs of the contemporary globalised or in other words knowledge society.
\end{abstract}

Keywords: contemporary public spaces, knowledge and innovation spaces, place making, quality of urban life, Brisbane

To cite this article:

Pancholi, S., Guaralda, M., Yigitcanlar, T. (20I7). Context, contribution and characteristics of public spaces for place making in contemporary knowledge and innovation spaces. Observations from Brisbane, Australia. The Journal of Public Space, 2(4), 9I-I02. DOI: 10.5204/jps.v2i4.I43

This article has been peer-reviewed and accepted for publication in The Journal of Public Space.

Please see the Editorial Policies under the 'About' section of the journal website for further information.

cC) (F) This work is licensed under a Creative Commons Attribution - Non Commercial 4.0

International License - https://creativecommons.org/licenses/by-nc/4.0/ 


\section{Introduction}

Public spaces lie at the core of democratic living (Carr et al., 1992). They become the centre stage of urban life facilitating the encounters and exchange of experiences between diverse people and traditions. This, in turn, contributes in strengthening the roots of a tolerant urban society (Worpole \& Greenhalgh, 1996). Zukin (1995) defines them as the locus for continuous production of symbols giving meaning to the contemporary culture. Public spaces have been defined in a myriad of ways across multi-disciplinary literature through different lenses that include-but not limited to-land tenure, accessibility or social interaction. Moreover, the key role played by public spaces in the creation of local identity and developing a sense of place is widely acknowledged (Zukin, 1995; Carmona, 2003; Pancholi et. al., 20I5a). However, the role of public spaces in facilitating place making in the globalised context of emerging knowledge based urban development (KBUD) has remained an under-investigated subject-which forms the particular focus of this study (KBUD) (Yigitcanlar et al., 2007; Van Winden, 20I0; Pancholi et al., 20I5a). Policymakers around the world have accepted KBUD as the elixir for all social, economic, environmental and spatial challenges (Lonqqvist et al., 20I4). Globally the acceptance of KBUD as the most sustainable path to attain long-term competitiveness has manifested into the consequent emergence of new typology of knowledge milieus in the form of knowledge and innovation spaces (KISs) (Knight, 1995; Asheim, 2007; Kunzmann, 2008; Yigitcanlar, 20I0; Pancholi et. al., 20I4, 20I5a, 20I5b, 20I7). One-north (Singapore), Macquarie park innovation district (Sydney), Silicon Valley, Silicon Alley (New York), Silicon Roundabout (London), Orestad (Copenhagen), Brainport (Eindhoven), Parkville Knowledge Precinct (Melbourne) and Kelvin Grove Urban Village (Brisbane) are few of their many successful examples around the world. Planners and policymakers are searching for effective strategies to attract and retain skilled human capital in the form of knowledge workers to these KISs (Yigitcanlar et al., 2007; Florida, 20I2). However, this emerging class of knowledge workers is highly mobile and displays special lifestyle choices (Zenker, 2009). Place making, therefore, has been accepted as a key strategy here for retainment of knowledge workers (Pratt, 2002; Sheppard, 2002; Pancholi et al., 2014, 20I5b, 20I7).

Urban design is implemented as a key process of facilitating place making for a specific context (Carmona, 2003). While design defines and characterises the experience of a locale, places are also the product of different, i.e., socio-cultural, economic and so onlayers of society and get constantly charged with different symbols and meanings (Buttimer, 1980; Creswell, 2004; Arefi, 2014). Places are also shaped through indirect design factors such as establishment of policy, investment decisions and management (Carmona, 2003). Recent works by scholars such as Shaftoe (20I2) highlight that the production of successful public spaces require a comprehensive approach manifesting a fair interplay of design and management overarched by the broader framework of urban policies. This is further supported by Ken Worpole (2005) who highlights design's inadequacy to solve a problem by itself being placed into the deeper layers of social and economic values and circumstances. In addition, in the globalised spaces, the process of urban design does not only revolve around people and place but is also influenced by the variables generated by global flows, markets and regulations (Adams \& Tiesdell, 20 I3; Kabachnik, 20I0). An integrated approach—that includes consideration and comprehension of both physical and social-cultural dimension-is, therefore, considered 
necessary for understanding public spaces and successful place making in KISs (Duff, 2010; Massey, 2005).

This paper aims to explore two major questions:

RQ I: What are the conditions for place making in public spaces of contemporary KISs?

RQ 2: What are the key characteristics of public spaces to facilitate place making in this context?

In order to provide preliminary answers to these questions, two cases of the established KISs in Brisbane, the capital city of Queensland, Australia, are discussed. Australia-one of the fastest growing economies - has Brisbane as its key emerging knowledge centre (Yigitcanlar et al., 2008a; Yigitcanlar \& Velibeyoglu, 2008b). Other cities such as Sydney and Melbourne have been advancing into the same direction at a fast pace following the pathway of KBUD. (Yigitcanlar, 20I0). This paper seeks to establish an understanding of the key attributes that characterise the nature of public spaces in the contemporary KISs. To do so, the paper investigates two KISs in Brisbane evaluating the key design strategies implemented to develop a sense of place in two. A basic conceptual framework of characteristics derived from an exploration of existing literature is utilised for analysis. The paper aims to fill the gap in theoretical understanding regarding public spaces in the newer context of these emerging knowledge spaces.

\section{Case in point-Context framing for Brisbane}

KBUD and knowledge and innovation spaces in Brisbane

KIS is considered as the spatial core for the generation and transfer of knowledge in KBUD (Yigitcanlar et al., 2008c). Yigitcanlar and Lonnqvist (2013) put KBUD in a nutshell as a multi-dimensional policy aiming at efficient business, people, place and governance climate and their integration. Henceforth, the four main pillars of KBUD are summarised as economy, society, environment and governance (Yigitcanlar, 20I4b). The city of Brisbane-one of the emerging knowledge cities in Australia_received one of its major spatial transformation after the implementation of few significant policies of Queensland government that include 'Smart City Strategy' and 'Smart State Strategy' (Yigitcanlar, 2008a). With specific concentration on socio-cultural development and knowledge sector, these policies were a major breakthrough to establish the city in a global knowledge economy. (Mort and Roan, 2003; Wiltshire, 2003). The pentagon prism model that forms the base of Smart City Strategy overarches five aspects: creative, administrative, business, natural and built environments, with connectivity playing a crucial role in strengthening local and global linkages (Yigitcanlar et al., 2008a). The focus of the policies, therefore, can be seen to have a shift from the modest local economic development to the more ambitious KBUD perspective (Smyth et al., 2004).

The strong foundation of Brisbane in diverse knowledge industry sectors such as biotechnology and biosciences, aviation and aerospace, and information technology has stimulated the development of KISs in and around the city-with some in developmental stages while others already developed and functional (Yigitcanlar \& Velibeyoglu, 2008b). These include-but not limited to-Kelvin Grove Urban knowledge village, Boggo Road knowledge precinct, Brisbane Technology Park, Mt Gravatt Research Park, Da Vinci airport precinct as well as close ones such as Sunshine Coast knowledge town (Sunshine Coast) and Griffith university precinct (Gold Coast). 
Knowledge workers in Brisbane

Creative class thesis of Florida (2002) — based on the idea of the 3T's-Technology, Talent and Tolerance - is at the center of development of KISs. Florida (2002) asserts the central importance of knowledge workers in the success of global economy. With about $21 \%$ of Brisbane's population being young, focused attention is being given to the knowledge workers in the policies. Being aimed at making youth engaged, empowered, valued and celebrated, Youth Strategy 2014-2019 formulated recently is an evidence of this (Youth Strategy, 20l4).

Zenker (2009) identifies few characteristics that make the knowledge workers distinct. They are well-informed, participative, critical, and politically active; seek a better quality of life with healthier habits and are less dependent on consumption; culturally active and artistically expressive; displaying diversity and tolerance; having higher competency in human relations (Carrillo, 2004). Meeting the special needs and understanding the characteristics of these social groups is necessary for attracting the creative class and creating a place for them in the city (Zenker, 2009). In addition to knowledge workers' specific preferences, progressive sense of place that gets attached to place making in KISs has transfigured the objectives of contemporary public spaces in KISs (Carrillo, 2004; Pancholi et al., 20I4).

Contemporary public spaces of knowledge and innovation spaces In the globalised world, progressive sense of place is manifested in the production of permanence by the integration of global flows and processes in a locale (Massey, 1991; Lippard, 1997; Creswell, 2004). Carr et al. (1992) summarises the list of key attributes that define public spaces as: responsive, comforting, meaningful, democratic (in accessibility, expression and rights), engaging (passively and actively) and providing a sense of discovery. With the onset of 'open innovation' era, KISs are becoming more open and aim for sustainable generation, transfer and transmission of knowledge-which manifests as the major reason for their contribution in socio-economic growth of cities and regions (Chesbrough, 2003; Yigitcanlar et al., 2008c). They, hence, attach a new purpose to public spaces in addition to the above mentioned characteristics outlined by Carr et al. (1992). In addition to being the focal points serving for relaxation, entertainment and engagement, public spaces in KISs also have to act as the foremost point of connection between the knowledge space and the city, allowing the maximum seepage of knowledge within its boundaries as well as outside its boundaries (Pancholi et al., 20I5a). Contemporary public spaces in KISs, therefore, have two key objectives to simultaneously act as a: (i) Platform for the development of sense of place and permanence in the knowledge workers; and (ii) Medium that facilitates the flows and processes of knowledge (Pancholi et al., 2015a).

\section{Methodology and framework}

The case of Brisbane is investigated to better identify the attributes of place making in public spaces of KISs. Two specific locations within this city are analysed: Boggo Road knowledge precinct, and Kelvin Grove urban knowledge village. A review of government documents and policies is framed by the theoretical background discussed in the literature review section. The analytical framework is adopted from research study by Pancholi et al. (20I5) that includes two major dimensions. These refer to: (i) 'Character' that refers to scale, character, climate and environment; and (ii) Connectedness referring 
to the spatial and virtual connectivity. This corresponds to the derived objectives of public spaces too. Character analyses the sense of place while connectedness analyses the facilitation of knowledge dissemination. The selected cases are analysed at two levels: (i) Development of sense of place and permanence by character is investigated within the precinct, and; (ii) Connectedness of progressive place to facilitate the external and internal flows is being analysed at city level, considering the give-and-take process at a broader scale.

\section{The case of Brisbane's two knowledge and innovation spaces}

Boggo Road Knowledge Precinct is an inner city development situated in vicinity of major health and research facilities-i.e., the Princess Alexandra and Mater Hospitals and the University of Queensland. The precinct is based on the historic Boggo Road Gaol, a heritage listed building. The surrounding Brownfield has been redeveloped with a focus on bioinformatics, biomedical and ICT. With the driving vision to be known as an enviroculturally responsible project, this development is currently in its initial development phase with about $40 \%$ of the project completed.

Kelvin Grove Urban Village is instead a well-established suburb and an example of successful knowledge community. It is also considered a landmark project in the development of Brisbane (Charles, 20I I). It is based on the triple-helix model i.e. a joint venture between the university, public and private sectors. Queensland university of Technology acts as the key anchor project with its widespread presence on the site. The intervention centred on creative industries and biosciences is marketed for its vibrant and creative live-work-learn-play environment.

Analysing planning documents and the intended urban form, is possible to evaluate how both these precincts have some common design characteristics (Refer Figures I \& 2):

- Contextual character: In the cases of Boggo Road knowledge precinct and Kelvin Grove Urban Village, sub-tropical design principles have been used for development. This is reflected in the climate-sensitive built form depicting traditional Queensland architectural features like awnings, lattice, screens and so on.

- Compact development: Both these precincts have a dense and compact built-form.

- Anchor: An impactful presence of a main building/campus that binds the whole site together by holding other buildings.

- Presence of an axis: A main street is designed leading to the anchor project. The main axis is characterised by mixed land uses. This boulevard acts as the main spine of KIS with all the main economic, institutional, commercial and public activities distributed around it.

- Central publiclopen space: The public/open spaces have been given a central role as well as a central location in the selected cases.

- Interconnected public spaces: Public spaces, of varying scale and character, are arranged around main axis and hence are interconnected with each other.

- Visual vistas: Open vistas within the built spaces emphasises a sense of unity into the precinct and provide visual connectivity to the broader context.

- Human-scale: Attention has been paid to ensure scaling down of urban form by the use of architectural features such as podiums or awnings and also by controlling the height. 
- Pedestrian environment: An extensive network of pedestrian roads is laid all through the site. To further strengthen pedestrian friendly environment, creative landscaping, sculptures, art integration, casual seatings have been provided.

- Engaging lower floors: In order to provide an exposure of the research activities running behind the walls of buildings, a visual engagement with the public spaces is established by the use of transparent facades and provision of commercial activities at the lower floor.

Table I shows a summarised outline of the major features identified in both KISs; it analyses elements within the precinct and in the broader context, revealing the relationship of KIS with the external world, as shown below:

Table I: Comparison between the major features in each KIS

\begin{tabular}{|c|c|c|c|c|}
\hline $\begin{array}{l}\text { Place } \\
\text { level }\end{array}$ & $\begin{array}{l}\text { Derived } \\
\text { attribute: }\end{array}$ & $\begin{array}{l}\text { Attribute } \\
\text { addressed }\end{array}$ & $\begin{array}{l}\text { Boggo Road knowledge } \\
\text { precinct (Refer figure I) }\end{array}$ & $\begin{array}{l}\text { Kelvin Grove urban village } \\
\text { (Refer figure 2) }\end{array}$ \\
\hline \multirow[b]{3}{*}{ W } & \multirow{4}{*}{$\begin{array}{l}\text { Contextualit } \\
y \\
\text { (Attachment } \\
\text { of meanings) }\end{array}$} & Character & $\begin{array}{l}\text { Responds to the } \\
\text { heritage listed gaol }\end{array}$ & $\begin{array}{l}\text { Responds to the historical } \\
\text { military context }\end{array}$ \\
\hline & & \multirow[t]{2}{*}{ Human scale } & $\begin{array}{l}\text { Low heighted (up to } 9 \\
\text { storeys) blends into the } \\
\text { context }\end{array}$ & Up to 7 storeys high \\
\hline & & & $\begin{array}{l}\text { Pedestrian friendly } \\
\text { streetscape with } \\
\text { outdoor dining and } \\
\text { coffee shops }\end{array}$ & $\begin{array}{l}\text { Pedestrian friendly } \\
\text { streetscape by high level of } \\
\text { detailing in pavements, } \\
\text { street furniture, use of } \\
\text { artworks, landscaping }\end{array}$ \\
\hline \multirow{2}{*}{$\begin{array}{l}\mathrm{T} \\
\mathrm{H}\end{array}$} & & Environment & $\begin{array}{l}\text { Low impact medium } \\
\text { density housing blends } \\
\text { with environment }\end{array}$ & $\begin{array}{l}\text { Blend of nature with man- } \\
\text { made structures }\end{array}$ \\
\hline & \multirow{6}{*}{$\begin{array}{l}\text { Connectedn } \\
\text { ess } \\
\text { (Attachment } \\
\text { of meanings) }\end{array}$} & \multirow[t]{3}{*}{ Spatial } & Mixed use environment & $\begin{array}{l}\text { Blurring of boundaries } \\
\text { between living and learning }\end{array}$ \\
\hline \multirow[t]{5}{*}{$\mathrm{N}$} & & & $\begin{array}{l}\text { Permeable built forms } \\
\text { enabling activities of } \\
\text { anchor project being } \\
\text { visible to public domain }\end{array}$ & $\begin{array}{l}\text { Seamless integration of } \\
\text { main project with built } \\
\text { environment and } \\
\text { accessibility to public to all } \\
\text { display areas of university }\end{array}$ \\
\hline & & & $\begin{array}{l}\text { Physical connections } \\
\text { between the public } \\
\text { spaces through buildings }\end{array}$ & $\begin{array}{l}\text { Interconnected open space } \\
\text { network }\end{array}$ \\
\hline & & Visual & $\begin{array}{l}\text { Visual linkages } \\
\text { established between } \\
\text { various elements of } \\
\text { precinct }\end{array}$ & $\begin{array}{l}\text { Concept of 'Eyes on street' } \\
\text { by houses overlooking the } \\
\text { public spaces }\end{array}$ \\
\hline & & \multirow{2}{*}{$\begin{array}{l}\text { Socio- } \\
\text { cultural } \\
\text { vibrancy }\end{array}$} & \multirow{2}{*}{$\begin{array}{l}\text { Collaborative } \\
\text { environment within the } \\
\text { precinct }\end{array}$} & The popular local markets \\
\hline & & & & $\begin{array}{l}\text { Integration of local } \\
\text { artworks in landscaping }\end{array}$ \\
\hline
\end{tabular}

96 | The Journal of Public Space, 2(4), 2017| ISSN 2206-9658

(c) Queensland University of Technology 


\begin{tabular}{|c|c|c|c|c|}
\hline \multirow[b]{3}{*}{$E$} & \multirow{3}{*}{\begin{tabular}{|l} 
Context \\
(Flows and \\
Processes)
\end{tabular}} & \multirow[t]{2}{*}{ Character } & $\begin{array}{l}\text { In harmony with the } \\
\text { inner city CBD }\end{array}$ & $\begin{array}{l}\text { In harmony with the inner } \\
\text { city CBD }\end{array}$ \\
\hline & & & $\begin{array}{l}\text { High-tech built } \\
\text { environment based on } \\
\text { knowledge and urban } \\
\text { lifestyle gives a global } \\
\text { character }\end{array}$ & $\begin{array}{l}\text { High-tech built } \\
\text { environment based on } \\
\text { knowledge and urban } \\
\text { lifestyle gives a global } \\
\text { character }\end{array}$ \\
\hline & & Climate & $\begin{array}{l}\text { Awarded for its } \\
\text { sustainable design } \\
\text { concerns }\end{array}$ & $\begin{array}{l}\text { Climate- responsive: } \\
\text { Tropical design }\end{array}$ \\
\hline $\mathrm{T}$ & \multirow{6}{*}{$\begin{array}{l}\text { Connectedn } \\
\text { ess } \\
\text { (Flows and } \\
\text { processes) }\end{array}$} & \multirow[t]{2}{*}{ Spatial } & $\begin{array}{l}\text { Main roads and train } \\
\text { tracks block the edges } \\
\text { making it less permeable }\end{array}$ & $\begin{array}{l}\text { Considerable integration } \\
\text { with the neighbourhoods }\end{array}$ \\
\hline $\mathrm{R}$ & & & $\begin{array}{l}\text { Well connected by } \\
\text { transport to other parts } \\
\text { of city but less } \\
\text { permeable boundary }\end{array}$ & $\begin{array}{l}\text { Well connected by } \\
\text { transport to other parts of } \\
\text { city but less permeable } \\
\text { boundary }\end{array}$ \\
\hline A & & \multirow[t]{2}{*}{ Visual } & \multirow[t]{2}{*}{$\begin{array}{l}\text { Emphasis on vistas } \\
\text { opening up for outside } \\
\text { views like CBD }\end{array}$} & $\begin{array}{l}\text { Views of Victoria Park Golf } \\
\text { course, undulating adjacent } \\
\text { suburbs and CBD }\end{array}$ \\
\hline \multirow[t]{3}{*}{$\mathrm{L}$} & & & & $\begin{array}{l}\text { Views from residences } \\
\text { towards the } \\
\text { CBD/mountains }\end{array}$ \\
\hline & & \multirow[t]{2}{*}{$\begin{array}{l}\text { Socio- } \\
\text { cultural } \\
\text { vibrancy }\end{array}$} & $\begin{array}{l}\text { Lack of social activities } \\
\text { that integrate it with } \\
\text { outer world }\end{array}$ & $\begin{array}{l}\text { Local markets attract the } \\
\text { visitors from other part of } \\
\text { the city but this needs to } \\
\text { be enhanced }\end{array}$ \\
\hline & & & Lack of cultural events & Lack of cultural events \\
\hline
\end{tabular}

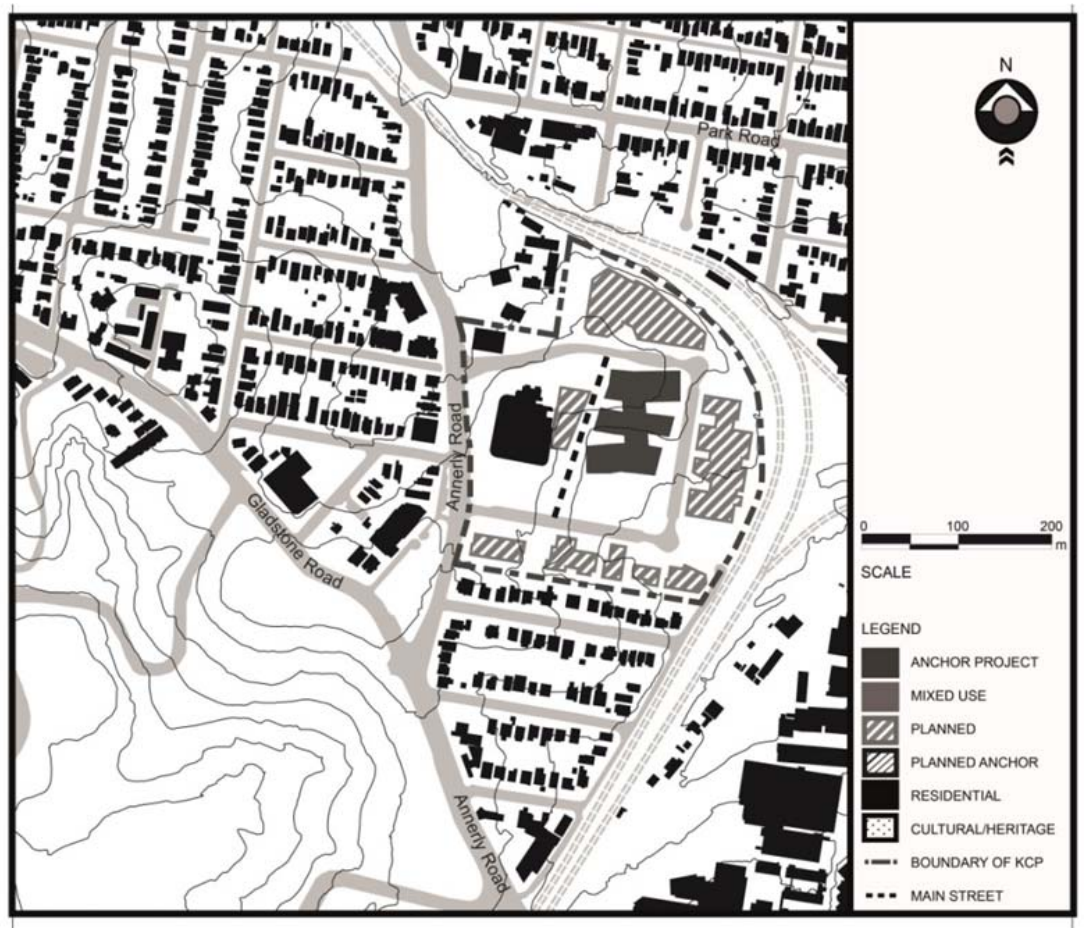

Fig. I: Boggo road knowledge precinct [Diagram by Guaralda M. (20/3)] 


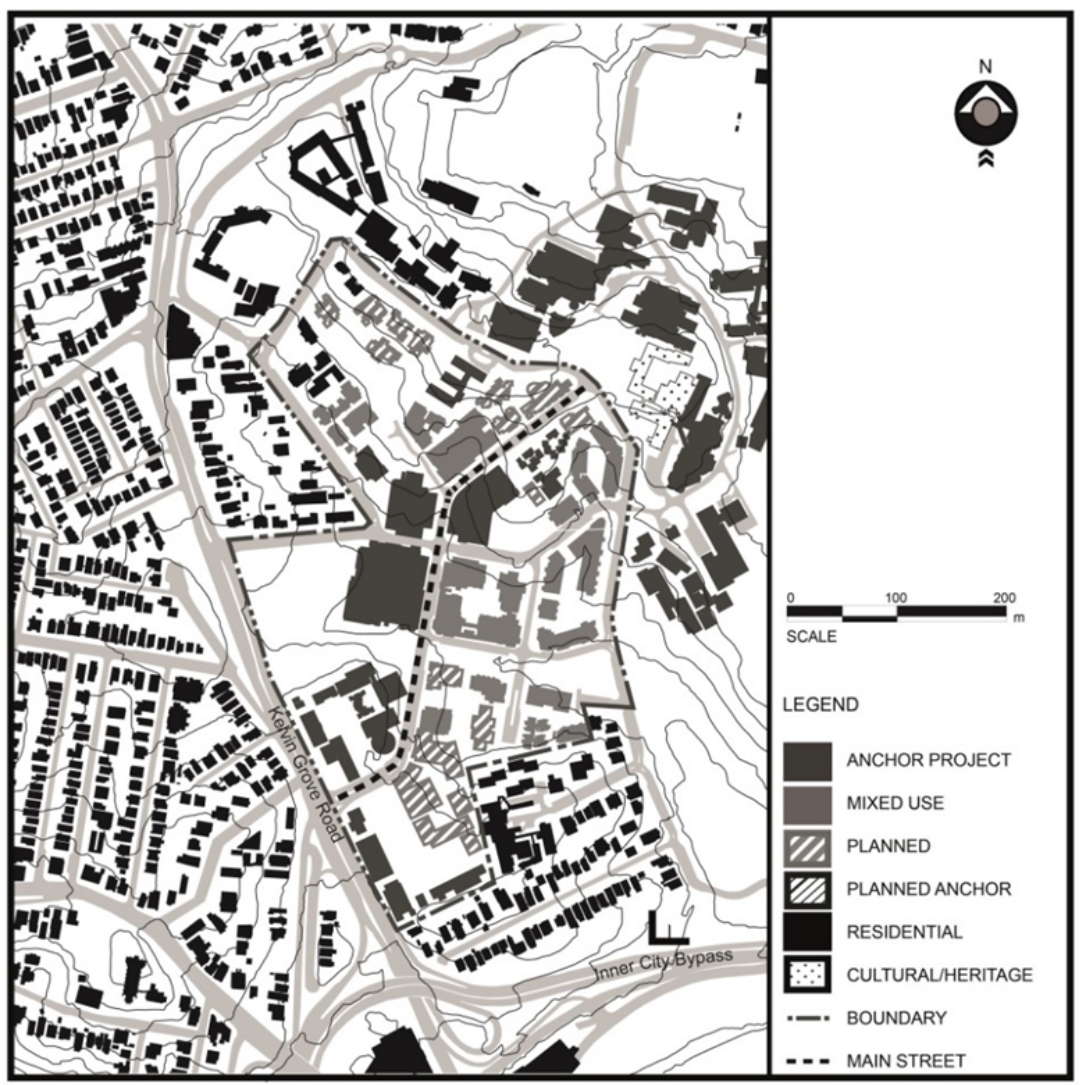

Fig. 2: Boggo Road knowledge precinct [Diagram by Guaralda M. (20/3)]

An investigation of case studies leads to identification of 'permeability' as a major attribute that define public spaces of contemporary KISs that contributes in facilitating a progressive sense of place making for knowledge workers. More importantly, permeability refers not only in spatial but also in economic, social and environmental terms-as evident in both the cases.

It is possible to conclude that new defining characteristics of permeable typology can be summated as:

- Spatial permeability: Spatially, this is seen by the presence of: (i) Mixed land uses: Blurred boundaries between living, working and playing is one of the key defining quality of these places. (ii) Permeable urban form: Physical and visual connectivity is promoted throughout the precinct by the interconnections between public spaces and opening up of internal vistas. (iii) Permeable built forms: The facades of public and anchor project buildings are designed as transparent towards the public domain to allow maximum visibility of activities going inside in order to engage people outside. The windows, entrances and also footpath uses at lower floors enables active street frontage (iv) External vistas: Both these precincts visually connect to the outer world by opening up the vistas towards CBD and surroundings.

- Social permeability: Social permeability, in such KISs, is seen to be manifested in following aspects: (i) Contexuality: In both the cases of KGUV and BRKP, careful consideration has been taken for development of these places in response to the original context. This assists in the communication of local arts and history to the 
migrant population and develop a sense of place by helping them attach meaning to the place; (ii) Connectedness: The display of local music, arts and crafts as a part of the weekly market in Kelvin Grove is an attempt to communicate the local knowledge assets to the knowledge workers. Such markets also act as a platform for people from various cultures to display their arts, culture and music, thus giving all the social groups an equitable chance to express them. The use of ICT for providing wireless communication within the precinct also enhances the internal connectedness, and; (iii) Integration of Diversity: Emphasis has been laid to provide a variety of housing typologies responding to the choices of people from all social and cultural layers. But again in the above two cases, the social and cultural activities are not yet seen to be effectively sufficient to make the social layer permeable with the city and region attracting visitors from outside and letting the knowledge seep down throughout.

- Economic permeability: Economic permeability is seen at two levels: (i) Economic ownership: Knowledge and innovation spaces, unlike the traditional precincts, are based on the triple helix model thus reflecting permeability in its economic model. It is a joint collaboration between the private, public and economic sectors, and; (ii) Affordability: The permeable character is reflected in the presence of economic options for all classes in such places. Special attention is being paid to develop activities catering to all economic groups.

- Environmental permeability: Care has been taken to blend the architecture with context by keeping it to a scale that matches its surroundings. In case of Boggo road knowledge precinct, the low impact, medium density housing blended with context is an example of permeability with environment. The built environment needs to keep itself permeable to the wildlife and nature around. Also, the provision of sustainable designs stresses upon the integration of nature with the man-made designs. Thus a considerable extent of permeability between natural and man-made environment is seen in both cases.

\section{Conclusion}

In the current era of open innovation, for any KIS to be globally successful and competitive, it is vital to develop a sense of place in knowledge workers that contributes in sustenance of talent as well as dissemination of ideas within and outside the precinct (Chesbrough, 2003; Van Winden et al., 20I3; Pancholi et al., 20I5b). The competitiveness between global cities has generated an attention to local contexts. The specific locale, with a unique sense of place, can provide that character and unique experience that young talent are looking for. Moreover, it also acts a medium for lubricating the flow of ideas. Our research demonstrates that a key role, here, is played by design of public domain that becomes a central element in such KISs. This paper has reviewed two case studies, one in its final stages (Kelvin Grove Urban Village) and one in its preliminary development stages (Boggo Road Knowledge Precinct). The investigated cases led us to identifying 'permeability' as the central attribute characterising the emerging public spaces of these contemporary KISs and contributing in their adaptation as per the changing needs of this globalised context. This refers to a comprehensive and multi-layered permeability, i.e., in spatial, social, economic and environmental terms. The research also suggested certain common design features as evident in implementation of Brisbane's strategy to plan their emerging KISs. These include existence of an anchor project, spinal main axis and, most 
importantly, a permeable and connected layout. A local typology responsive to the local tropical climate and Australian culture of traditional outdoor living can be very evidently seen to be manifesting itself. Hence, KISs in Brisbane, though each having a different context and identity, are all proliferating as permeable typology driven by some common underlying principles shaping them.

In practice, planners and policymakers engaged in place making in contemporary KISs should, therefore, attempt to integrate multi-layered permeability as a key attribute. Physical development policies that encourage mixed-land uses and planning of horizontally and vertically connected spaces can be done to strengthen spatial permeability.

Establishing formal and informal groups and organising events and functions that integrate socially diverse community are few of the initiatives for strengthening social permeability. To strengthen economic permeability, planning of diverse range of affordable spaces and encouraging an equal participation by various groups of stakeholders-including public, private, academia and community-needs to be implemented. Policies and strategies that encourage the context-sensitive development-which include cultural, climatic and social context - will strengthen environmental permeability. Integration of permeability in design and development of their public spaces as well as the entire planning and development of KISs will lead to maximum circulation of knowledge within the precinct as well as from the precincts to the overall veins of the city and, in the process, actively attaining the objective of place making for the knowledge workers. The findings from this research can be utilised for future research in aligned areas such as critical analysis of place making and smart city strategies. In addition, a more detailed and extensive exploration into diverse context such as other Australian cities and larger focus on the social aspects of place making as tool for developing successful public spaces in contemporary KISs will be addressed as a part of future research.

\section{References}

Adams, D., \& Tiesdell, S. (20/3). Shaping places: urban planning, design and development. New York: Routledge.

Amin, A. \& Graham, S. (1997). The ordinary city. Transactions of the Institute of British Geographers. 22, $41 \mathrm{I}-429$.

Arefi, M. (2004). The pedagogy of the American city: Revisiting the concepts of place, non-place, and placelessness. URBAN DESIGN International, 9, I03-II 7.

Asheim, B. (2007). Differentiated knowledge bases and varieties of regional innovation systems. Innovation: The European Journal of Social Sciences, 20(3), 223-24I.

Brisbane City Council , Brisbane City (2003). Creative City: Brisbane City Council's Cultural Strategy 2003-2008. Policy Document.

Brisbane City Council, Brisbane City (2005). Kelvin Grove Urban Village local plan. Planning Document.

Brisbane City Council, Brisbane City (2007). City Shape Implementation Strategy 2003-2008. Planning Document.

Brisbane City Council, Brisbane City (2014). Youth Strategy 2014-2019: Delivering a youth friendly city. Policy Document.

Butina-Watson, G. (2006, November, 2006). Local distinctiveness: identity by design. Paper presented at the Subtropical Cities 2006 Conference: Achieving Ecologically Sustainable Urbanism in a Subtropical Built Environment, Brisbane, Australia. 
Buttimer, A., Seamon, D. (Ed.). (1980). The Human Experience of Space and Place. London: Croom Helm.

Carmona, M., Heath, T., Oc, T., \& Tiesdell, S. (2010). Public Places Urban Spaces: The dimensions of Urban Design. UK: Architectural Press.

Carr, S., Francis, M., Rivlin, L.G., \& Stone, A. (1992). Public space. Cambridge: Cambridge University Press.

Casey, E. (1998). The Fate of Place:A Philosophical History. Berkeley: University of California Press.

Casey, E. S. (200I). Between Geography and Philosophy: What Does It Mean to Be in the PlaceWorld? Annals of the Association of American Geographers, 9I (4), 683-693.

Chesbrough, H. (2003). The era of open innovation. MIT Sloan Management Review 44(3): 35-4I.

Cresswell, T. (2004). Place: A short introduction. London: Wiley.

Duff, C. (20I0). On the role of affect and practice in the production of place. Environment and Planning D: Society and Space, 28(5), 88I-895.

Felsenstein, D. (1994). University-related science parks. Technovation, I4(2), 93-I I0.

Florida, R. (2002). The economic geography of talent Annals of the Association of American Geographers, 92(I), 743-755.

Florida, R. (2002). The rise of the creative class: and how it's transforming work, leisure, community and everyday life. New York: Basic Books.

Florida, R. (2012). The rise of the creative class:Revisited. New York:Basic books.

HRPPC (Humpreys Reynolds Perkins Planning Consultant) (2007). Boggo Road Urban Village Structure plan. Planning Document.

Kabachnik, P. (2010). England or Uruguay? The persistence of place and the myth of the placeless Gypsy. - 42(- 2), - 207.

KGUV (2012). Kelvin Grove Urban Village. Accessed from www.kgurbanvillage.com.au on 12 Apr 2014.

Knight, R. V. (1995). Knowledge-based development: policy and planning implications for cities. Urban Studies, 32(2), 225-260.

Kunzmann, K., (2008). Spatial dimensions of knowledge production. In T. Yigitcanlar, K. Velibeyoglu \& S.Baum (Eds.), Knowledge-based urban development. Hersey: IGI Global, 296300.

Lippard, L. (1997). The Lure of the Local: Senses of Place in a Multicultural society. New York: The New Press.

Lonnqvist, A., Kapyla, J., Salonius, H., \& Yigitcanlar, T. (20I4). Knowledge that matters: identifying regional knowledge assets of Tampere Region, European Planning Studies.

Massey, D. (I99I). A global sense of place. Marxism today, 35(6), 24-29.

Mort, G., Roan, A. (2003) Smart state: Queensland in the knowledge economy, Queensland Review, 10(I), 859-870.

MSC (Maroochy Shire Council) (2000). Development of Sippy Downs town centre. Planning document.

MSC (Maroochy Shire Council) (2007). Local growth management strategy. Planning document.

Pancholi, S., Yigitcanlar, T., Guaralda, M. (20I4). Urban knowledge and innovation spaces. Asia Pacific Journal of Innovation and Entrepreneurship, 8(I): 15-38.

Pancholi, S., Yigitcanlar, T., Guaralda, M. (20I5a) Public space design of knowledge and innovation spaces. Journal of Open Innovation, I(I): I3.

Pancholi, S., Yigitcanlar, T., Guaralda, M. (2015b) Place making facilitators of knowledge and innovation spaces. International Journal of Knowledge-Based Development, 6(3): 2I 5-240.

Pancholi, S., Yigitcanlar, T., Guaralda, M. (2017) Governance that matters. Journal of Place Management and Development, IO(I): 73-87.

Pratt, A.C. (2002). Hot jobs in cool places:The material culture of new media product spaces: The case of south of the market, San Fransisco. Information, communication and society, 5(I), p. 27.

QG (Queensland Governemnt) (200I). Kelvin Grove Urban Village. The village news brochure. 
QG (2002). Kelvin Grove Urban Village. Urban village brochure.

QG (2004b). Kelvin Grove Urban Village. Design guidelines planning document.

QG (2004b). Kelvin Grove Urban Village. Creative community brochure.

QG (2004c). Smart Queensland: Smart State Strategy 2005-2015. Policy document.

QG (2009). Boggo Road Urban Village at Dutton Park. Project Update Brochure.

QG (2008b). Kelvin Grove Urban Village. Development opportunities brochure.

QG (2010). Kelvin Grove Urban Village. Design guidelines planning document.

Shaftoe, H. (2008). Convivial Urban Spaces: Creating Effective Public Spaces. LLC: Earthscan.

Sheppard, E. (2002). The spaces and times of globalization: Place, scale, networks, and positionality. Economic Geography, 78(3), 307-330.

Van Winden, W. (20I0). Knowledge and the European city. Economic and Social Geography, I0I(I), $100-106$.

Wiltshire, K. (2003). Queensland Smart State: Positioning Queensland. Queensland Review, IO(I), $\mathrm{I}-\mathrm{IO}$.

Worpole, Ken,Greenhalgh, Liz. (1996). The freedom of the city. London: Demos.

Yigitcanlar, T., Baum, S., \& Horton, S. (2007). Attracting and retaining knowledge workers in knowledge cities. J. Knowledge Management, I I(5), 6-I7.

Yigitcanlar, T., O'Connor, K., \& Westerman, C. (2008a). The making of knowledge cities: Melbourne's knowledge-based urban development experience. Cities, 25(2), 63-72.

Yigitcanlar, T., Velibeyoglu, K.. (2008b). Knowledge-Based Urban Development: The Local Economic Development Path of Brisbane, Australia. Local Economy, 23(3), 195-207.

Yigitcanlar, T., Velibeyoglu, K., \& Martinez-Fernandez, C. (2008c). Rising knowledge cities: the role of knowledge precincts. J. Knowledge Management, I2(5), 8-20.

Yigitcanlar, T. (2010). Making space and place for the knowledge economy: knowledge-based development of Australian cities. European Planning Studies, I8(I I), I 769-I 786.

Yigitcanlar, T. \& Dur, F. (20I3). Making space and place for knowledge communities: lessons for Australian practice, Australian J. Regional Studies, 19(1), 36-63.

Yigitcanlar, T., \& Lönnqvist, A. (2013). Benchmarking knowledge-based urban development performance: Results from the international comparison of Helsinki. Cities, 3I(I), 357-369.

Yigitcanlar, T., \& Lee, S., (20/4). Korean ubiquitous-eco-city: a smart-sustainable urban form or a branding hoax. Technological Forecasting and Social Change, http://dx.doi.org/10.1016/j.techfore.2013.08.034.

Yigitcanlar, T. (20I4b). Position paper: benchmarking the performance of global and emerging knowledge cities, Expert Systems with Applications, http://dx.doi.org/10.1016/j.eswa.2014.03.032.

Zenker, S. (2009). Who's your target? The creative class as a target group for place branding, J. Place Management and development, I2(5), 8-20.

Zukin, S. (2010). Naked city: the death and life of authentic urban places. Oxford; New York: Oxford University Press. 